\title{
Z Kuşağının Kariyer Beklentileri: Lise Öğrencileri Üzerinde Bir Uygulama
}

\author{
Career Expectations of Generation Z: An Application on High School Students
}

\author{
Gökhan $\ddot{U N L} \ddot{U} *$ \\ Hüseyin ÇIÇEK ${ }^{* *}$
}

$\ddot{O} Z$

Her bireyin dünyaya geldiği zaman aralığında teknolojik, ekonomik ve çevresel şartlar değişim göstereceğinden bu değişim bireyin kişiliğinde ve kariyer beklentisinde de etki edeceği düşünülmektedir. Bu düşünce doğrultusunda yıllar baz alınarak kuşakların sınıflandırılması yapılmıştır. Literatürde farklı sınıflandırmaların yer alması sebebiyle çalışmamızda Fox (2011) 'in sınıflandırması kullanılmıştır. Bu sınıflandırmalardan hareketle en genç kuşă̆ı, Z kuşağının oluşturduğu görülmektedir. Henüz iş yaşamında aktif olarak katılım göstermemekte olan Z kuşağı bireyleri yavaş yavaş iş yaşamında varlık göstermeye başladı. Teknoloji ile birlikte gelişip büyüyen bu kuşak bireylerinin hayata bakış açıları ve geleceğe yönelik tutum ve davranışları diğer kuşak bireylerine göre farklılık göstermektedir. Bu farklılıklardan hareketle $Z$ kuşağı bireylerinin kariyer ve gelecek beklentileri ölçülmesi çalışmanın amacını oluşturmaktadır. Bu amaç doğrultusunda Isparta merkezde bulunan ve liselerde ĕgitim görmekte olan 451 ögrenci üzerinde anket uygulaması yapılmıştır. Araştırmada McWhirter ve McWhirter (2008) tarafindan geliştirilen FESA (Future Expectations Scale for Adolescents) ölçeğinin Tuncer (2011) tarafindan Türkçeye uyarlaması olan Ergen Gelecek Beklentileri Ölçeği (EGBÖ) kullanılarak ölçüm yapılmıştır. Verilerin çözümlenmesinde frekans analizi, açımlayıcı faktör analizi, bağımsız örneklem t testi, anova testi ve korelasyon analizi uygulanmıştır. Yapılan analizler ortalama ve standart sapmalarla belirlenmiş olup bu doğrultuda Z kuşağı bireyleri ile kariyer beklentileri arasında anlamlı farklılıklar bulunduğu tespit edilmiştir.

ANAHTAR KELIMELER

Kuşaklar, Z Kuşă̆ı, Kariyer Beklentisi, Öğrenciler

\begin{abstract}
Since the technological, economic and environmental conditions will change in the time period in which each individual comes into the world, this change is thought to affect the personality of the individual. In line with this idea, the generations were classified based on years. Based on these classifications, it is seen that the youngest generation is formed by the $Z$ generation. $Z$ generation individuals who have not been actively involved in business life have begun to appear in business life. The perspectives of this generation of individuals who develop and grow with technology and their attitudes and behaviors towards the future differ according to other generation individuals. Based on these differences, the aim of the study is to measure career and future expectations of Z generation individuals. For this purpose, a questionnaire was applied on 451 students in Isparta center and in high schools. McWhirter Research and McWhirter (2008) developed by FESA (Future Expectations Scale for Adolescents) scale of Tuncer (2011) Turkish by an adaptation Adolescent Future Expectations Questionnaire (EGBÖ) measurements were conducted using. Frequency analysis, exploratory factor analysis, independent sample t test, anova test and correlation analysis were used to analyze the data. The analyzes were determined by mean and standard deviations and it was determined that there were significant differences between $Z$ generation individuals and career expectations.
\end{abstract}

\section{KEYWORDS}

Generations, Generation Z, Career Expectations, Students

\begin{tabular}{|c|c|c|}
\hline & $\begin{array}{c}\text { Makale Geliş Tarihi / Submission Date } \\
\text { 21.03.2019 }\end{array}$ & $\begin{array}{c}\text { Makale Kabul Tarihi / Date of Acceptance } \\
\text { 19.09.2019 }\end{array}$ \\
\hline Atıf & \multicolumn{2}{|c|}{$\begin{array}{l}\text { Ünlü, G. ve Çiçek, H. (2019). Z Kuşağının Kariyer Beklentileri: Lise Öğrencileri Üzerinde Bir Uygulama. Selçuk } \\
\text { Üniversitesi Sosyal Bilimler Meslek Yüksekokulu Dergisi, } 22 \text { (2), 447-458. }\end{array}$} \\
\hline
\end{tabular}

\footnotetext{
* Yüksek Lisans Öğrencisi, Mehmet Akif Ersoy Üniversitesi, Sosyal Bilimler Enstitüsü, İşletme Anabilim Dalı, gokhanunlu@ ogr.mehmetakif.edu.tr, ORCID: 0000-0003-0753-4470

** Doç.Dr., Mehmet Akif Ersoy Üniversitesi, İIBF, İşletme Bölümü, hcicek@ mehmetakif.edu.tr, ORCID: 0000-0002-8284-7955
} 


\section{GİRIŞ}

Kuşak kavramı literatürde derin bir çalışma alanına sahip bir konu olması sebebiyle ön plana çıkmaktadır (Williams, 2015). Literatür incelemesi sonucunda kuşakların farklı kaynaklarda değişik sınıflandırmalar ve başlıklar altında toplandığı görülmektedir (Yiğit, 2010; Akdemir ve diğ. 2013; Keyles, 2005). Bu çalışmada kuşaklar kavramsal olarak kuşaklar beş ana başlık altında incelenmektedir. İnternet ve teknoloji ile gelişip büyümekte olan Z kuşağı ise bu çalışma alanının bir grubunu oluşturmaktadır. Z kuşağını diğer kuşaklardan ayıran en önemli özelliği, internet ve teknoloji ile iç içe olmasıdır (People, 2016; Sladek ve Grabinger, 2014). Bu kuşağın bireyleri, tüketimin fazla olduğu bir topluluğun içerisinde büyümektedir. Z kuşağı bireylerinin bireysel çalışma yönleri daha ağır basmaktadır. Bu kuşağın çalışma hayatına yeni giriyor olması, $Z$ kuşağı bireylerinin iş yaşamları hakkında çabuk sıkılabilecekleri ve işten kolay vazgeçebilecekleri tahminleri üzerinde durulmaktadır (Taş ve diğ. 2017). Bu kuşak bireylerinin çabuk kavrama ve aynı anda birden fazla işi yapabilme yetenekleri, iş hayatında başarılı olacaklarını bir garantisi olarak düşünülebilir. Z kuşağı bireylerinin, özgüveni yüksek ve kariyer odaklı bir nesil olduğunu söyleyebiliriz. Yapılan bu çalışmada kuşakların içerisinde, teknoloji odaklı gelişim gösteren ve yakın zamanda iş yaşamında yerini almaya başlayacak olan Z kuşağ bireylerinin kariyer beklentilerinin ne doğrultuda olduğu konusunda kavramsal inceleme yapılmıştır. Yapılan inceleme sonrasında ise araştırma verilerinin analizleri sonucunda elde edilen bulgular doğrultusunda araştırmaya yönelik olarak değerlendirmeler yapılmıştır. Teknoloji ile büyüyüp gelişmekte olan Z kuşağ1 yetişkin olduklarında gelecekten beklentileri üzerinde ve kariyer hedeflerinin ortaya çıkarılması hususu çalışmanın amacını oluşturmaktadır.

\section{KUŞAKLAR VE Z KUŞAĞI}

Kuşak kavramı kaynaklarda farklı olarak tanımlanmaktadır. Türk Dil Kurumunda yer alan kuşak, aşağı yukarı aynı tarih aralığında doğmuş ve aynı çağın koşul ve sıkıntılarını paylaşmış olan kişilerin oluşturduğu grup olarak tanımlanmaktadır. (http://www.tdk.gov.tr). Kuşak birbirine benzer zaman aralığında doğmuş ve birbirine benzer şekilde yaş ve aynı yaşam dönemini paylaşan ve bu yaşam döneminde belirli olay ve olguları kendileri tarafindan şekillendirilmiş olan insan topluluğunu ifade etmek için kullanılmaktadır (Keleş, 2011). Yapılan bir başka çalışmada ise kuşak, aynı dönem içerisinde yaşamakta olan ve birbirleri ile aynı özellikleri bulunan bireylerin oluşturmuş oldukları gruplar olarak tanımlanmaktadır. (Adıgüzel ve diğ. 2014). Tüm bu tanımlardan hareketle kuşak kavramın; aynı tarih aralığında doğmuş ve bu tarih aralığındaki koşul ve sıkıntılardan olumlu veya olumsuz olarak etkilenmiş bunu yanı sıra birbirleriyle ortak özellikleri olan bir insan topluluğu olarak ifade edebiliriz. Söz konusu olan bu kuşakların isimlendirilmesi ve yıl olarak sınıflandırılmasında farklı görüşler olduğu görülmektedir. Bu farklı görüşler Tablo.1 de görülmektedir.

Tablo.1: Farklı Kaynaklarda Yer Alan Kuşak Sınıflandırmaları

\begin{tabular}{|c|c|c|c|c|c|}
\hline Kaynaklar & \multicolumn{5}{|c|}{ Kuşak Sınıflandırmaları } \\
\hline $\begin{array}{c}\text { Howe ve Strauss } \\
(2000)\end{array}$ & $\begin{array}{c}\text { Sessiz Kuşak } \\
(1925-1943)\end{array}$ & $\begin{array}{c}\text { Patlama Kuşağ } \\
(1943-1960)\end{array}$ & $\begin{array}{c}\text { 13. Kuşak } \\
(1961-1981)\end{array}$ & $\begin{array}{l}\text { Milenyum Kuşağ } \\
(1982-2000)\end{array}$ & - \\
\hline $\begin{array}{c}\text { Lancaster ve } \\
\text { Stillman (2002) }\end{array}$ & $\begin{array}{l}\text { Gelenekçiler } \\
(1900-1945)\end{array}$ & $\begin{array}{c}\text { Bebek Patlaması } \\
\text { (1946-1964) }\end{array}$ & $\begin{array}{c}\text { X Kuşağ1 } \\
(1965-1980)\end{array}$ & $\begin{array}{l}\text { Milenyum Kuşağ1, } \\
\text { Patlama Kopyası, } \\
\text { Y Kuşağ1, } \\
\text { Gelecek Kuşak } \\
\text { (1981-1999) }\end{array}$ & - \\
\hline $\begin{array}{c}\text { Martin ve Tulgan } \\
\text { (2002) }\end{array}$ & $\begin{array}{c}\text { Sessiz Kuşak } \\
(1925-1942)\end{array}$ & $\begin{array}{c}\text { Bebek Patlaması } \\
(1947-1960)\end{array}$ & $\begin{array}{c}\text { X Kuşağ1 } \\
(1965-1977)\end{array}$ & $\begin{array}{l}\text { Milenyumlar } \\
(1978-2000)\end{array}$ & - \\
\hline $\begin{array}{l}\text { Oblinger ve } \\
\text { Oblinger } \\
(2005)\end{array}$ & $\begin{array}{l}\text { Yetişkinler } \\
(<1946)\end{array}$ & $\begin{array}{c}\text { Bebek Patlaması } \\
(1947- \\
1964)\end{array}$ & $\begin{array}{c}\text { X kuşağ1 (1965- } \\
1980)\end{array}$ & $\begin{array}{l}\text { Y Kuşağ1, Net } \\
\text { Kuşağ1 } \\
\text { Milenyumlar } \\
(1981-1995)\end{array}$ & $\begin{array}{l}\text { Milenyum Sonrası } \\
\text { (1995-Şimdi) }\end{array}$ \\
\hline $\begin{array}{l}\text { Tapscott } \\
(1998)\end{array}$ & - & $\begin{array}{c}\text { Bebek Patlaması } \\
\text { (1946-1964) }\end{array}$ & $\begin{array}{c}\text { X Kuşağ1 } \\
(1965-1975)\end{array}$ & $\begin{array}{l}\text { Dijital Kuşak } \\
(1976-2000)\end{array}$ & - \\
\hline Zemke ark & $\begin{array}{c}\text { Eski Askerler } \\
(1922-1943)\end{array}$ & $\begin{array}{c}\text { Bebek Patlamas1 } \\
(1943-1960)\end{array}$ & $\begin{array}{c}\text { X kuşağ } 1 \text { (1960- } \\
1980)\end{array}$ & $\begin{array}{l}\text { Gelecektekiler } \\
(1980-1999)\end{array}$ & - \\
\hline
\end{tabular}

Kaynak: Reeves ve Oh, 2008 
Tablo. 1 de yer alan farklı tanımlardan hareketle kuşaklar Sessiz Kuşak, Bebek Patlaması, X, Y ve Z Kuşağı olmak üzere 5'e ayrılarak sınıflandırıldığ görülmektedir. Bu kuşaklardan ilki olan Sessiz Kuşak 1925-1945 tarih aralığında doğmuş bireyleri ifade eder. Bebek Patlaması Kuşağı ise 1946-1964 yılları arasında doğmuş olan bireylerin oluşturmuş olduğu grubu ifade eder. Bir diğer kuşak olan X kuşağı ise Bebek Patlaması kuşağı bireyleri tarafından büyütülmüş olan 1965-1979 yılları arasında bulunan kişilerin oluşturduğu kuşağı ifade etmektedir. Y kuşağını ise 1980- ve 1999 yılları arasında dünyaya gelmiş olan bireylerin oluşturduğu kuşaktır. Son olarak da bu araştırmanın temel konusu olan Z kuşağını ise 2000 ve sonrasındaki yıllar arasında doğmuş kişilerden oluşmaktadır (Fox, 2011).Bu kişiler "Kuşak I", "İnternet Kuşağı", "Next Generation" veya "İ Gen" gibi adlarla isimlendirilmektedirler. Bunun yanı sıra bu kuşak bireylerine verilen bir diğer isim ise "Instant Online" (Her daim aktif) kuşağıdır (Lavicate, 2012; Strauss ve Howe, 2001). Söz konusu kuşaktaki bireyler X kuşağı tarafından büyütülmüşler ve Y kuşağı ile de etkileşim halinde olmuşlardır. Bu kuşak kriz, çevresel sorunlar ve bunun yanı sıra terörizm gibi zorluklarla karşı karşıya olan bir dünyada doğmuşlardır. Bu olumsuz gelişmelerin yanında $\mathrm{Z}$ kuşağı bireyleri internet, teknoloji vb. konularında psiko-motor becerileri ile birlikte etkili bir şekilde yaygın olarak kullanım ve gelişimine tanık olmuşlardır (Başol ve Aydın, 2014). Söz konusu olan bu psiko-motor beceri duyu organları, beyin ve kasların birbiriyle bağlantılı çalışmasından ortaya çıkan doğru ve uyumlu bir davranış bütünüdür (Şen, 2012). Bu sebepten dolayı kuşaklar içerisinde psiko-motor becerileri en gelişmiş olan bu kuşak bireyleri aynı anda birçok konu üzerinde düşünme ve yeteneklerini geliştirip kullanabilme kabiliyetine sahip bir kuşak olarak ön plana çıktığı görülmektedir.

Bu kuşağın hafızasının kuvvetli olmasından dolayı öğrenmede ezbercilikten çok oyun ve eğlenceli yol ve yöntemler kullanmaktadırlar (Büyükuslu, 2017). Kuşakların her birinin kendisine has karakteristik özellikleri, değer ve tutumları bunun yanı sıra güçlü ve zayıf yönlerinin olduğu söylenebilir. Buradan hareketle herhangi bir kuşağı ifade ederken kalıplaşmış sözlerin olduğunu göz ardı etmemek gerekir. Kuşakları belirli bir kalıp içerisinden tanımlama yaparken, bu kalıp içerisine giren her bir bireyin bu özellikleri taşıdığını söylemek doğru bir ifade değildir (Schwarz, 2008) Z kuşağı bireylerinin kariyer beklentilerinde etkili olan bir diğer faktör ise otorite kavramıdır. Otoriteyi elinde bulunduran işletme sahibinin kendisini bir birey olarak tanıyıp o şekilde bir yaklaşım sağlamasını beklemektedir. Bu özelliği ile de Y kuşağına benzemektedir (Boovee ve diğ. 2007).Şu halde birkaç yıl içerisinde aktif olarak iş hayatında da yer alacağını söylenen bu kuşak bireylerinin iş yaşamına dair özelliklerine göre,

$\mathrm{Z}$ kuşağında yer alan bireylerin iş yaşamlarında çalışacakları şirketlerin marka değerleri ve sunacakları sosyal imkanlar ile yakından ilgilendikleri ve yapacakları tercih sıralamasında ise bu iki faktörün etkili olacağı yapılan araştırmayla ortaya koyduğu düşünülmektedir (Sarığlu ve Özgen, 2017). Dolayısıyla Z kuşağı bireylerinin iş yaşamından varlığının artmasıyla birlikte daha çok ekranın var olacağı kuralların ve kâğıt israfının azalacağı bunun yanın sıra esnek bir çalışma saati sistemi içerisinde pek çok yeni görevlerin olacağ1 belirtilmektedir. Tıpkı bir sinema seti gibi proje ve geçici gruplar kurularak kadın ve erkeğin eşit olduğu bir çalışma ortamının gündeme geleceği ileri sürülmektedir (Taş ve diğ. 2017).

\section{KARIYYER VE KUŞAKLARIN KARIYYER BEKLENTISİ}

Kariyer kavramının ilk kullanımı 16. yüzyıldan bu zamana kadar olmasına rağmen insanlar ve iş yaşamı için ilk olarak bilimsel bir şekilde kullanılması Anne Roe'nun 1956 yılında kaleme aldığı "Meslekler Psikolojisi" kitabı ile ortaya çıkmaktadır. Bunun sonrasında ise 1957 yılında Donald E.Supper'in yazmış olduğu "Kariyer Psikolojisi", 1963 yılında Triedeman ve Ohara'nın "Kariyer Gelişimi, Seçimi ve Uyarlanması ile Bireysel Kariyer Gelişim Teorisi" ve bunlara ek olarak 1966 yılında John Holland'ın kaleme almış olduğu "Meslek Tercihi Teorisi" ile birlikte kariyer kavramı bir tartışma konusu olmuştur (Özgen ve Yalçın, 2015). Kariyer günlük dilde; meslek kollarında ve iş yaşamında daha ileriye gitmek, başarıyı yakalamak ve bireyin bütün bu iş yaşantısı boyunca üstlenmiş olduğu roller ile ilgili deneyimlerinin bütünü olarak tanımlanabilmektedir (Taşlıyan ve di ̆̆. 2011). Bu bütünlük içerisinde kariyer kavramı kullanılmaya başlandığı andan itibaren insanların aklında farklı tanımlar oluşmuştur. Bu kavramsallaştırma basit olabileceği gibi çok karmaşık anlamlarda da olabilmektedir. Literatür incelendiğinde kariyer kavramı ile ilgili birçok tanımla karşılaşılmaktadır (Eryiğit, 2000). Kariyer, bir iş görenin çalışma yaşamını anlatan süreçtir (Ergeneli ve diğ. 2016). Kariyer, bir kişinin hedeflemiş olduğu bir yaşam tarzı için uzun bir dönemde elde etmiş olduğu veya elde edebileceği eğitim, yetenek ve deneyimlerinin bir bütünü olarak tanımlanabilir (Anafarta, 2001). Farklı yönlerden tanımı yapılan kariyer kavramında ortak bir yönden bakıldığında, bir ölçüt olarak "başarı derecesini" çağrıştırmasıdır.

Bu bağlamda kariyer sözcüğü planlama olarak da değerlendirilmektedir. Kariyer planlama kişinin iş hayatında sahip olduğu veya olmak isteyeceği ve olumlu olarak kullanıldığında ise duymaktan hoşlanabileceği bir sözcüktür (Atay, 2006). Bu sözcük planlama bağlamında da değerlendirilmektedir. Kariyer planlaması, iş 
hayatında arzu ettiği sonuçları başarabilmesi için amaçların belirlenmesini içermektedir. Kariyer planlaması, kişilerin yapmış oldukları işlerde daha verimli ve mutlu olmalarını sağlayabilmektedir (Aydemir, 2018). Bir kariyer planını uygun bir şekilde yapılmış olması sayesinde bir yönetim, daha gelişmiş olan ve hedef odaklı çalışanların desteğinden keyif alarak, çalışanlarının kaygılarını inceleyerek onların iş performanslarını arttırabilmelerine ve gelecekte bu firsatlardan yararlanabilmelerine imkan sağlamaktadır (Tanoli, 2016). Kariyer planlaması motivasyon ve kaliteyi bunların yanında ise bireyin ve işletmenin hedeflerini ortak bir noktada buluşturarak bunun sonucunda ise verimliliğin arttırılması için insan kaynakları departmanının vazgeçilmez bir uygulaması haline gelmiştir. Kariyer planlamasının temel amacı olarak örgütün etkinlik ve verimliliğinin arttırılması olduğunu söylenebilir (Taşlıyan, 2011). Kariyer gelişimi, bireyin kendi ait kariyer planlarına ulaşmasını ve başarıyı elde edebilmesini sağlayacak bir anlamı ifade etmekle birlikte kariyer planının başarılı olarak uygulanabilmesi için gerekli olan faaliyetleri içermektedir (Aşkun, 2006).

\subsection{Z Kuşağı İle Kariyer Beklentisi İlişkisi}

Z kuşağı ile kariyer beklentisinin ilişkisi teorik ve ampirik çalışmalarla incelenmiştir. Bu doğrultuda literatürde yapılan birçok çalışma olduğu bilinmektedir. Örneğin; Bilici (2015)'in gerçekleştirmiş olduğu turizm eğitimi almış sektör çalışanlarının kariyer beklentileri (Fethiye örneği) adlı çalışmasında otel çalışanlarının kariyer beklentisi algıları cinsiyete, aldıkları eğitime ve çalıştıkları departmana göre anlamlı bir farklılık bulunmazken; sektörde çalışma süreleri arasında anlamlı bir farklılık tespit edilmiştir. Benzer bir çalışma olan Aydemir (2018)'in gastronomi ve mutfak eğitimi alan lisans öğrencilerinin kariyer beklentilerini ölçmek amacıyla yapılmıştır. Yapılan bu çalışmada ise öğrenim görülen sınıf, yaş ve ailenin aylık gelirleri ve kariyer beklentileri arasında ve gastronomi ve mutfak sanatları alanında staj yapmayan ve gastronomi ve mutfak sanatları alanında staj yapan öğrencilerin kariyer beklentileri arasında anlamlı farklılıkların olduğu tespit edilmiştir. Özdemir (2010)'in ön lisans muhasebe öğrencilerinin kariyer planlamasını etkileyen unsurlar konulu çalışma da öğrencilerin meslek tercihlerine etki eden faktörleri "prestij, mesleki avantajlar ve meslek güvencesi" olarak üç ana başl1kta toplamıştır. Metin ve diğg. (2017)'in yapmış olduğu bir diğer çalışma olan X ve Y kuşaklarının kariyer beklentilerinin farklılaşması konulu araştırmasında ise otomotiv sektöründe faaliyet gösteren bir işletmede ise $\mathrm{Y}$ kuşağı çalışanlarının kariyer beklentilerinin X kuşağına göre farklılık gösterdiği tespit edilmiştir. Öte yandan Tosun ve diğ. (2018)'in yapmış olduğu üniversite öğrencilerinin kariyer beklentileri ve empati eğilimleri konulu çalışmalarında ise bölüm, bursluluk durumu, anne ve babanın işlerine göre farklılıklar bulunamamış ancak cinsiyet, ikamet edilen yere ve kardeş sayısına göre ise anlamlı farkl111k bulunmaktadir.

\section{METEDOLOJI}

\subsection{Araştırmanın Evreni ve Örneklemi}

Değişen ve yenilenen çevre koşullarının da etkisiyle insan yaşamında önemli bir yere sahip olan kariyer, bireylerin gelecekle ilgili beklentilerinin belirlenimlesin de vazgeçilmez bir yere ve öneme sahip kavramdır. Bu önem doğrultusunda hazırlanmış olan bu çalışmanın evrenini 2018-2019 eğitim ve öğretim yılında 41 tane lisede öğrenim görmekte olan 14.593 lise öğrencisi oluşturmaktadır. Söz konusu bilgiler ek 1'de sunulmaktadır. $\mathrm{Bu}$ araştırma Fen Lisesi, Anadolu Lisesi ve Meslek liselerinde öğrenim görmekte olan 451 lise öğrencisine uygulanmıştır. Kolaylama örnekleme yöntemi ile ulaşılan bu kişi sayısıyla yüz yüze anket çalışması uygulanmış ancak 67 öğrencinin anketteki bazı sorulara cevap vermediği için kullanılmamış olup, 384 lise öğrencisinden elde edilen veriler üzerinden çalışma gerçekleştirilmiştir. Bu örneklem sayısına göre \%95 güven aralığında Baş (2005: 47)'ın belli sayıda evren büyüklüğüne ilişkin örneklem sayılarını içeren tablosu dikkate alındığında araştırma için yeterli olduğu kabul edilmektedir.

\subsection{Araştırmada Veri Toplama Aracı ve Yöntemi}

Araştırmada McWhirter ve McWhirter (2008) tarafindan geliştirilen FESA (Future Expectations Scale for Adolescents) ölçeğinin Türkçeye uyarlaması olan Ergen Gelecek Beklentileri Ölçeği (EGBÖ) kullanılmıştır (Tuncer, 2011). Orijinal ölçek 25 maddeden ve dört boyuttan oluşmaktadır. Söz konusu olan bu boyutlar iş ve eğitim, evlilik ve aile, din ve toplum, sağlık ve yaşamdır. Bu dört faktörlü yapının Cronbach Alfa katsayısı 0,925 olarak bulunmuştur.

\subsection{Araştırma Verilerin Analizi}

Araştırma verilerinin analizinde SPSS 20. paket programından yararlanılmıştır. Araştırma verilerinin analizinde ilk olarak katılımcıların demografik özelliklerini ifade eden bulgular sunulmuş ve frekans analizi yapılmıştır. Sonrasında ölçeğin güvenirlik katsayısını bulmak için Cronbach's Alpha katsayısı hesaplanmıştır.

Selçuk Üniversitesi Sosyal Bilimler Meslek Yüksekokulu Dergisi, Yıl: 2019 Cilt: 22 Sayı:2 
Ardından ölçeğin yapı geçerliliğini belirlemek amacıyla açımlayıcı faktör analizi uygulanmıştır. Faktörler arası ilişkiyi tespit etmek amacıyla korelasyon analizi yapılmıştır. Son olarak bağımsız örneklem T testi ve faktörler arası ilişkiyi tespit edebilmek için korelasyon analizine başvurulmuştur.

\section{ARAŞTIRMANIN BULGULARI}

\subsection{Araştırmanın Genel Bulguları}

Araştırmaya katılım gösteren bireylerin demografik özelliklerini ölçmek amacıyla yönetilen sorulara ilişkin değerler tablo 2'de yer almaktadır. Tablo 2'den elde edilen verilere göre araştırmaya katılan öğrencilerin 189 'unu $(\% 49,2)$ kız, 195'i $(\% 50,8)$ ise erkek öğrenciler oluşmaktadır. Öğrenciler yaş aralıkları ise 53'ü (\%13.8) 14 yaşında, 139 'ü (\%36.2) 15 yaşında, 75'i $(\% 19,5) 16$ yaşında, 92'si $(\% 24,0) 17$ yaşında ve 25'i $(6,5)$ ise 18 olarak dağılım göstermektedir. Öğrencilerin 180'i (\%46,9) Lise-1, 72'si $(\% 18,8)$ Lise-2, 72'si $(\% 18,8)$ Lise-3 ve 60'1 (\%15,6) Lise-4. sınıfında eğitim görmektedir. Öğrenciler 51'i $(13,3)$ Fen Lisesi, 297'si $(\% 77,3)$ Anadolu Lisesi ve 36's1 $(9,4)$ Meslek Lisesi öğrencisidir.

Tablo 2. Demografik Bulgular

\begin{tabular}{|c|c|c|c|}
\hline $\mathrm{N}=384$ & Gruplar & $N=384$ & Yüzde \\
\hline \multirow{2}{*}{ Cinsiyet } & $\mathrm{K} ı \mathrm{z}$ & 189 & 49,2 \\
\hline & Erkek & 195 & 50,8 \\
\hline \multirow{5}{*}{ Yaş } & 14 & 53 & 13,8 \\
\hline & 15 & 139 & 36,2 \\
\hline & 16 & 75 & 19,5 \\
\hline & 17 & 92 & 24,0 \\
\hline & 18 & 25 & 6,5 \\
\hline \multirow{4}{*}{ Sınıf } & Lise-1 & 180 & 46,9 \\
\hline & Lise-2 & 72 & 18,8 \\
\hline & Lise-3 & 72 & 18,8 \\
\hline & Lise-4 & 60 & 15,6 \\
\hline \multirow{3}{*}{ Okul Türü } & Fen Lisesi & 51 & 13,3 \\
\hline & Anadolu Lisesi & 297 & 77,3 \\
\hline & Meslek Lisesi & 36 & 9,4 \\
\hline
\end{tabular}


Tablo 3. Kariyer Beklentisi Ölçeğinin Faktör Analizi ve Güvenilirlik Katsayıları

\begin{tabular}{|c|c|c|c|c|}
\hline Kariyer Beklentisi & 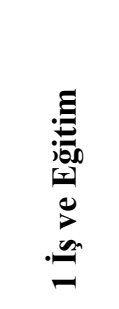 & 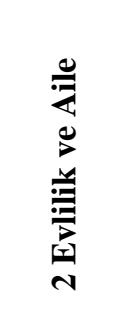 & 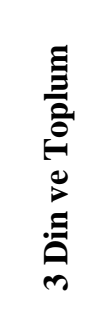 & 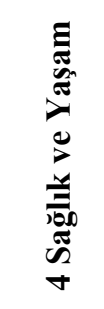 \\
\hline 1.Hayatımla ilgili başarmak istediğim şeyleri başarmış olacağım. &, 832 & & & \\
\hline 2.İstediğim şeyleri satın alabileceğim. &, 819 & & & \\
\hline 3.İyi bir iş bulacağım. & ,797 & & & \\
\hline 4.Hedeflediğim eğitim düzeyine ulaşacağım. & ,778 & & & \\
\hline 5.Hoşlanacă̆ım bir iș bulacağım. &, 768 & & & \\
\hline 6.İstikrarlı bir iş bulacağım. & ,761 & & & \\
\hline 7.Geçimimi her zaman sağlayacağım. & ,717 & & & \\
\hline 8.Kendimi güvende hissedeceğim. &, 712 & & & \\
\hline 9.Kazandığım para bana ve hayat arkadaşıma yeterli gelecek. & 677 & & & \\
\hline 10İşim bana kendimle gurur duymam için firsatlar verecek. & 579 & & & \\
\hline 11.Mutlu bir hayatım olacak. &, 558 & & & \\
\hline 12.Evleneceğim. & & ,842 & & \\
\hline 13.Çocuklarım olacak. & & 830 & & \\
\hline 14.25 yaşından önce evli olacağım. & &, 577 & & \\
\hline 15.Evliliğim hep sürecek. & & 805 & & \\
\hline 24.Çocuğum daima barış içinde yaşayacak. & & ,768 & & \\
\hline 25.Çocuğumun uzun bir hayatı olacak. & & ,724 & & \\
\hline 23.Çocuğuma güvenli bir ortam sağlayacağım. & & ,764 & & \\
\hline 17.Düzenli olarak toplumsal ve dini hizmetlere katılacağım. & & & 860 & \\
\hline 16.Dini aktivitelere katılacağım. & & & 884 & \\
\hline 18.Topluluğumda lider olacağım. & & & ,526 & \\
\hline 20.Uzun bir hayat yaşayacağım. & & & & 627 \\
\hline 21.Sağlıklı bir diyet yapacağım. & & & & ,770 \\
\hline 22.Spor yapacağım. & & & & ,742 \\
\hline 19.Sağlığım iyi olacak. & & & & ,791 \\
\hline Boyutların Varyans Açıklama Yüzdeleri & 37,579 & 11,693 & 7,642 & 5,447 \\
\hline Açıklanan Toplam Varyans & \multicolumn{4}{|c|}{$\% 62,361$} \\
\hline Keiser-Meyer-Olkin & \multirow{2}{*}{\multicolumn{4}{|c|}{$\frac{, 911}{5790,800}$}} \\
\hline Barlett Sphericity & & & & \\
\hline Boyutların Güvenilirlik Değerleri & ,927 & 899 & ,760 & ,750 \\
\hline
\end{tabular}

Tablo 3'deki açımlayıcı faktör analizine göre; Açıklanan toplam varyans 62,361 olup, toplam varyansın \%37,579'u iş ve eğitim boyutunu, \%11,693'ü evlilik ve aile boyutunu, \%7,642'si din ve toplum boyutunu ve $\% 5,447$ 'si ise sağlık ve yaşam boyutunu açıklamaktadır.

\subsection{Korelasyon Analizi}

Çalışmanın bu kısmında kariyer beklentisi boyutları ile demografik verilerin arasındaki ilişkiyi tespit etmek amacıyla korelasyon analizi yapılmıştır. Analiz sonucu tablo 4'de yer almaktadır. Bu doğrultuda cinsiyetin kariyer beklentisi boyutlarından ilki olan iş ve eğitim boyutu ile anlamlı bir ilişkisinin olduğu ancak evlilik ve aile, din ve toplum, sağlık ve yaşam boyutları ile herhangi bir anlamlı ilişkisi bulunmadığını görülmektedir $(\mathrm{p}>0,05)$. Öte yandan kariyer beklentisi algısındaki din ve toplum boyutunun yaş ile arasındaki ilişki incelendiğinde pozitif yönlü anlamlı bir ilişkinin varlığı görülmekte $(p>0,05)$ ancak iş ve eğitim, evlilik ve aile, sağlık ve yaşam boyutlarının herhangi bir ilişkisinin bulunmadığı ifade edilebilmektedir. Bunun yanı sıra sınıfın, kariyer beklentisi boyutları olan iş ve eğitim, evlilik ve aile, din ve toplum sağlık ve yaşam ile pozitif yönde anlamlı bir ilişkinin olduğunu söyleyebiliriz $(\mathrm{p}<0,001)$. Dolayısıyla kariyer beklentisi boyutunun sınıf üzerinde etkili bir rolünün olduğu ifade edilebilir. Son olarak ise okul türünün kariyer beklentisi boyutlarından iş ve eğitim, evlilik ve aile boyutları ile anlamlı bir ilişkisinin olduğu ifade edilebilirken $(p<0,05)$ okul türünün 
din ve toplum, sağlık ve yaşam boyutları ile herhangi bir anlamlı ilişkinin olmadığı analiz sonuçları arasında yer almaktadır ( $p>0,05)$. Şu halde okul türünün öğrencilerin hem iş ve eğitimin hayatında hem de aile hayatında önemli bir yere sahip olduğu düşünülebilir.

Tablo 4. Araştırma Değişkenlerine İlişsin Korelasyon Analizi

\begin{tabular}{|c|c|c|c|c|c|c|c|c|}
\hline $\mathrm{N}=384$ & 1 & 2 & 3 & 4 & 5 & 6 & 7 & 8 \\
\hline 1. Cinsiyet & 1 & & & & & & & \\
\hline 2. Yaş &, 365 & 1 & & & & & & \\
\hline 3. Sınıf & ,405 &, 257 & 1 & & & & & \\
\hline 4. Okul Türü &, 895 & ,645 &, 005 & 1 & & & & \\
\hline 5. İş ve Eğitim & ,036 &, 743 & ,000 &, 063 & 1 & & & \\
\hline 6. Evlilik ve Aile &, 257 & ,201 &, 000 & ,092 &, 000 & 1 & & \\
\hline 7. Din ve Toplum &, 376 & 063 & ,000 &, 145 &, 000 &, 000 & 1 & \\
\hline 8. Sağlık ve Yaşam &, 0405 & 257 &, 134 & 005 & 000 & 000 & 000 & 1 \\
\hline
\end{tabular}
$* * * \mathbf{p}<0,001 ; * * \mathbf{p}<0,01 ; * \mathbf{p}<0,05$

Araştırmaya katılan öğrencilerin kariyer beklentisi sorularına vermiş oldukları cevapların ortalamalarının cinsiyete göre anlamlı olup olmadığını ölçmek amacıyla Bağımsız Örneklem T Testi (Independest Samples t Test) analizi yapılmıştır. Analiz sonucu tablo 5'de yer almaktadır. Yapılan analiz sonucunda cinsiyetin, kariyer beklentisi boyutlarından biri olan iş ve eğitim boyutu ile istatistiksel olarak anlamlı bir ilişkiye sahip olduğu görülmektedir $(\mathrm{p}<0,05)$. Öte yandan kariyer beklentisi boyutlarından bir diğeri olan evlilik ve aile boyutu ile cinsiyet arasında istatistiksel olarak anlamlı bir ilişki bulunamamıştır. Kariyer beklentisi boyutlarından din ve toplum boyutu ile de cinsiyet arasında istatistiksel anlamda bir ilişki bulunmazken son olarak sağlık ve yaşam boyutu ile cinsiyet arasında istatistiksel anlamda bir ilişki bulunamadığı yapılan analiz sonucunda görülmektedir.

Tablo 5. Cinsiyete Göre Bağımsız Örneklem T Testi Sonuçları

\begin{tabular}{|c|c|c|c|c|c|c|}
\hline $\mathrm{N}=384$ & Cinsiyet & $\mathbf{N}$ & Ortalama & S.S. & $\mathbf{t}$ & $\mathbf{P}$ \\
\hline \multirow{2}{*}{ İş ve Eğitim } & $\mathrm{K} ı \mathrm{z}$ & 189 & 4,0134 & 67533 & \multirow{2}{*}{4,431} & \multirow{2}{*}{, $036^{*}$} \\
\hline & Erkek & 195 & 3,8448 & ,87792 & & \\
\hline \multirow{2}{*}{ Evlilik ve Aile } & $\mathrm{Kız}$ & 189 & 3,3152 & ,79832 & \multirow{2}{*}{1,289} & \multirow{2}{*}{,257 } \\
\hline & Erkek & 195 & 3,4122 &, 87300 & & \\
\hline \multirow{2}{*}{ Din ve Toplum } & $\mathrm{Kız}$ & 189 & 3,9630 & 1,13213 & \multirow{2}{*}{, 785} & \multirow{2}{*}{,376 } \\
\hline & Erkek & 195 & 3,8607 & 1,12942 & & \\
\hline \multirow{2}{*}{ Sağlık ve Yaşam } & $\mathrm{Kız}$ & 189 & 3,2324 & ,98390 & \multirow{2}{*}{ 694 } & \multirow{2}{*}{,405 } \\
\hline & Erkek & 195 & 3,3128 & ,90828 & & \\
\hline
\end{tabular}

$* * * \mathbf{p}<0,001 ; * * \mathbf{p}<0,01 ; * \mathbf{p}<0,05$

Araştırmaya katılan öğrencilerin kariyer beklentisi sorularına vermiş oldukları cevapların ortalamalarının yaşa göre anlamlı olup olmadı̆̆ını ölçmek amacıyla tek yönlü varyans (Anova) analizi yapılmıştır. Yapılan 
analiz sonucu tablo 6'de yer almaktadır. Öğrencilerin yaşları ile kariyer beklentisi boyutu olan iş ve eğitim boyutuyla istatistiksel olarak anlamlı bir ilişki bulunamamıştır $(\mathrm{p}>0,05)$. Öte yandan kariyer beklentisi boyutlarından bir diğeri olan evlilik ve aile boyutu ile öğrencilerin yaşları arasında istatistiksel anlamda bir ilişki bulunmamaktadır. Diğer bir boyut olan din ve toplumun, yaş ile istatistiksel olarak anlamlı bir farkın olmadığı görülmektedir. Kariyer beklentisinin son boyutu olan sağlık ve yaşam ile cinsiyet arasında istatistiksel olarak anlamlı bir ilişki bulunmadığı görülmektedir.

Tablo 6. Yaşa Göre Tek Yönlü Varyans Analizi (Anova) Sonuçları

\begin{tabular}{|c|c|c|c|c|c|c|}
\hline $\mathrm{N}=384$ & Yaş & $\mathbf{N}$ & Ortalama & S.S. & $\mathbf{F}$ & $\mathbf{P}$ \\
\hline \multirow{5}{*}{ İş ve Eğitim } & 14 & 53 & 3,8830 & ,65641 & \multirow{5}{*}{, 578} & \multirow{5}{*}{,672 } \\
\hline & 15 & 139 & 3,8980 & ,83172 & & \\
\hline & 16 & 75 & 4,0521 & ,78263 & & \\
\hline & 17 & 92 & 3,8992 & ,79692 & & \\
\hline & 18 & 25 & 3,9200 &, 80474 & & \\
\hline \multirow{5}{*}{ Evlilik ve Aile } & 14 & 53 & 3,3041 & ,86083 & \multirow{5}{*}{, 807} & \multirow{5}{*}{, 522} \\
\hline & 15 & 139 & 3,3400 & ,82385 & & \\
\hline & 16 & 72 & 3,3524 & ,78469 & & \\
\hline & 17 & 92 & 3,3696 & ,87300 & & \\
\hline & 18 & 25 & 3,6457 & ,89416 & & \\
\hline \multirow{5}{*}{ Din ve Toplum } & 14 & 53 & 3,8679 & 1,12914 & \multirow{5}{*}{1,269} & \multirow{5}{*}{, 282} \\
\hline & 15 & 139 & 3,7710 & 1,25354 & & \\
\hline & 16 & 72 & 3,9911 & ,93155 & & \\
\hline & 17 & 92 & 3,9964 & 1,12524 & & \\
\hline & 18 & 25 & 4,2267 & ,92155 & & \\
\hline \multirow{5}{*}{$\begin{array}{l}\text { Sağlık ve } \\
\text { Yaşam }\end{array}$} & 14 & 53 & 3,3066 & ,89556 & \multirow{5}{*}{, 838} & \multirow{5}{*}{, 502} \\
\hline & 15 & 139 & 3,3693 & 1,06827 & & \\
\hline & 16 & 72 & 3,1867 & ,92734 & & \\
\hline & 17 & 92 & 3,1667 &, 84930 & & \\
\hline & 18 & 25 & 3,3200 & 68283 & & \\
\hline
\end{tabular}

Araştırmaya katılan öğrencilerin kariyer beklentisi sorularına vermiş oldukları cevapların ortalamalarının sınıflara göre anlamlı olup olmadığını ölçmek amacıyla tek yönlü varyans (Anova) analizi yapılmıştır. Analiz sonucu tablo 7'de yer almaktadır. Öğrencilerin eğitim aldıkları sınıflar ile kariyer beklentisinin iş ve eğitim boyutu ile arasında istatistiksel olarak anlamlı bir ilişki bulunmamaktadır. Ancak iş ve eğitim boyutunda, Lise2 düzeyinde ortalamanın yüksek olduğu görülmektedir $(4,1275 \pm, 76360)$. Öte yandan öğrencilerin sınıfları ile kariyer beklentisinin evlilik ve aile boyutunda sınıf ortalamalarının birbirlerine yakın olduğunu söyleyebiliriz. Kariyer beklentisinin din ve toplum boyutu ile sınıflar arasında istatistiksel anlamda bir ilişki bulunmamaktadır. Fakat din ve toplum boyutunda Lise-1 ve Lise-2 sınıflarının ortalarının birbirine yakınlık göstermesi aynı şekilde Lise-3, Lise-4 sınıflarının ortalamalarının da birbirine yakınlık gösterdiği görülmektedir. Bu bağlamda öğrencilerin okudukları sınıf düzeylerinin değişmesiyle din ve topluma ilişkinin de değişebileceği düşünülebilir. Son boyut olan sağlık ve yaşam ile öğrencilerin sinıfları arasında istatistiksel anlamda bir ilişki bulunmadığı görülmektedir. 
Tablo 7. Sınıflara Göre Tek Yönlü Varyans Analizi (Anova) Sonuçları

\begin{tabular}{|c|c|c|c|c|c|c|}
\hline $\mathrm{N}=384$ & Sinıf & $\mathbf{N}$ & Ortalama & S.S. & $\mathbf{F}$ & $\mathbf{P}$ \\
\hline \multirow{4}{*}{ İş ve Eğitim } & Lise-1 & 180 & 3,8676 & ,78928 & \multirow{4}{*}{2,040} & \multirow{4}{*}{, 108} \\
\hline & Lise-2 & 72 & 4,1275 & ,76360 & & \\
\hline & Lise-3 & 72 & 3,8699 & ,81051 & & \\
\hline & Lise-4 & 60 & 3,9379 & ,76656 & & \\
\hline \multirow{4}{*}{ Evlilik ve Aile } & Lise-1 & 180 & 3,3601 & ,83052 & \multirow{4}{*}{,495 } & \multirow{4}{*}{,686 } \\
\hline & Lise-2 & 72 & 3,2738 & ,82910 & & \\
\hline & Lise-3 & 72 & 3,4365 & ,86145 & & \\
\hline & Lise-4 & 60 & 3,4000 & 84936 & & \\
\hline \multirow{4}{*}{ Din ve Toplum } & Lise-1 & 180 & 3,8120 & 1,19953 & \multirow{4}{*}{1,164} & \multirow{4}{*}{, 323} \\
\hline & Lise-2 & 72 & 3,8981 & 1,02799 & & \\
\hline & Lise-3 & 72 & 4,0417 & 1,05844 & & \\
\hline & Lise-4 & 60 & 4,0667 & 1,11115 & & \\
\hline \multirow{4}{*}{$\begin{array}{c}\text { Sağlık ve } \\
\text { Yaşam }\end{array}$} & Lise-1 & 180 & 3,3894 & 1,03019 & \multirow{4}{*}{2,572} & \multirow{4}{*}{, 054} \\
\hline & Lise-2 & 72 & 3,0451 &, 87445 & & \\
\hline & Lise-3 & 72 & 3,2951 &, 87243 & & \\
\hline & Lise-4 & 60 & 3,1722 & ,79766 & & \\
\hline
\end{tabular}

$* * * \mathbf{p}<0,001 ; * * \mathbf{p}<0,01 ; * \mathbf{p}<0,05$

Araştırmaya katılan öğrencilerin kariyer beklentisi sorularına vermiş oldukları cevapların ortalamalarının okul türüne göre anlamlı olup olmadığını ölçmek amacıyla tek yönlü varyans (Anova) analizi yapılmıştır. Analiz sonucu tablo 8'de yer almaktadır. Yapılan araştırmada okul türünün, kariyer beklentisi boyutlarından ilki olan iş ve eğitim boyutu ile arasında istatistiksel olarak anlamlı bir ilişki bulunmamaktadır. Fakat ortalama yönünden baktığımız zaman meslek liselerinin ortalaması diğer okul türlerinden yüksek olduğu görülmektedir. $\mathrm{Bu}$ doğrultuda meslek lisesi öğrencilerinin kariyer beklentilerinde iş ve eğitimin önemli bir yere sahip olduğu ayrıca meslek lisesinde eğitim almaları bir avantaj olarak görülebilir. Diğer bir boyut olan evlilik ve aile ile okul türü arasında istatistiksel olarak bir anlamlı ilişki bulunmamakla birlikte okullar ortalamaları yönünden birbirine yakınlık gösterdiği görülmektedir. Buradan hareketle Z kuşağının bireyleri olan lise öğrencilerinin evlilik ve aile konusunda kariyer beklentilerinin birbirine benzerlik gösterdiği düşünülebilir. Bir başka kariyer beklentisi boyutu olan din ve toplum ile okul türleri arasında istatistiksel olarak anlamlı bir ilişki bulunmamaktadır. Öte yandan ortalama yönünden baktığımızda ise Anadolu ve meslek liselerinin ortalamalarının yüksek olduğu görülmektedir. Son boyut sağlık ve yaşam boyutu ile okul türleri arasında da istatistiksel olarak anlamlı bir ilişki yoktur. Ancak meslek lisesi ortalamasının diğer okul türlerine göre yüksek olduğu görülmektedir $(3,7222 \pm, 98339)$. 
Tablo 8. Okul Türüne Göre Tek Yönlü Varyans Analizi (Anova) Sonuçları

\begin{tabular}{|c|c|c|c|c|c|c|}
\hline $\mathrm{N}=384$ & Okul Türü & $\mathbf{N}$ & Ortalama & S.S. & $\mathbf{F}$ & $\mathbf{P}$ \\
\hline \multirow{3}{*}{ İş ve Eğitim } & Fen Lisesi & 51 & 3,7790 & ,89669 & \multirow{3}{*}{1,741} & \multirow{3}{*}{, 177} \\
\hline & $\begin{array}{c}\text { Anadolu } \\
\text { Lisesi }\end{array}$ & 297 & 3,9329 & ,76838 & & \\
\hline & Meslek Lisesi & 36 & 4,0960 & ,77229 & & \\
\hline \multirow{3}{*}{ Evlilik ve Aile } & Fen Lisesi & 51 & 3,2381 & ,97087 & \multirow{3}{*}{1,464} & \multirow{3}{*}{,233 } \\
\hline & $\begin{array}{c}\text { Anadolu } \\
\text { Lisesi }\end{array}$ & 297 & 3,3637 & ,81276 & & \\
\hline & Meslek Lisesi & 36 & 3,5496 & ,82576 & & \\
\hline \multirow{3}{*}{ Din ve Toplum } & Fen Lisesi & 51 & 3,6340 & 1,18744 & \multirow{3}{*}{1,775} & \multirow{3}{*}{,171 } \\
\hline & $\begin{array}{c}\text { Anadolu } \\
\text { Lisesi }\end{array}$ & 297 & 3,9545 & 1,12552 & & \\
\hline & Meslek Lisesi & 36 & 3,9444 & 1,06160 & & \\
\hline \multirow{3}{*}{$\begin{array}{l}\text { Sağlık ve } \\
\text { Yaşam }\end{array}$} & Fen Lisesi & 51 & 3,1127 & 1,03961 & \multirow{3}{*}{5,013} & \multirow{3}{*}{,007 } \\
\hline & $\begin{array}{c}\text { Anadolu } \\
\text { Lisesi }\end{array}$ & 297 & 3,2464 & ,91162 & & \\
\hline & Meslek Lisesi & 36 & 3,7222 & ,98339 & & \\
\hline
\end{tabular}

$\mathrm{Bu}$ araştırmada $\mathrm{Z}$ kuşağı kişilerin kariyer beklentilerini belirlemek amaçlanmıştır. $\mathrm{Bu}$ amaç doğrultusunda kariyer beklentisinin alt boyutları ile Z kuşağı bireylerin demografik verileri üzerinde anlamlı bir ilişkinin olduğu tespiti edilmiştir. Bu sonuç Aydemir (2018)'in yapmış olduğu gastronomi ve mutfak sanatları eğitimi alan üniversite öğrencilerinin kariyer beklentileri çalışmasındaki sonuç ile de örtüşmektedir. Öte yandan Üzüm ve diğ., (2015)'in gerçekleştirmiş olduğu bir başka benzer çalışmada ise cinsiyet ve öğrenim görülen alanda çalışma düşünceleri ile kariyer beklentilerin arasında bir ilişki bulunduğu görülmektedir. Bir başka çalışma olan Tuncer (2011)'in yapmış olduğu yükseköğretim gençliğinin kariyer beklentileri çalışmasında da cinsiyet ile gelecek beklentileri arasında anlamlı bir fark bulunmuştur. Bu anlamlı farklılık kız öğrencilerin lehindedir. Öğrencilerin gelecekteki kariyer beklentilerinde cinsiyetin önemi vurgulanmaktadır. Bu önem doğrultusunda ise Bilici (2015)'in yapmış olduğu turizm eğitimi almış sektör çalışanlarının kariyer beklentileri çalışmasında görüldügü gibi kariyer beklentileri ile cinsiyet arasında anlamlı farklılıklar bulunmuştur. Benzer şekilde Tosun ve diğ., (2018)'in yapmış olduğu bir başka çalışmada kariyer beklentileri ve cinsiyet arasında anlamlı bir ilişskinin olduğu sonucuna varılmıştır. Dolayısıyla yapılan bu çalışmanın sonucunda elde edilen bulgular literatürsel olarak da desteklenmektedir. Araştırmanın amacı ve önemi doğrultusunda ifade edildiği gibi kariyer insan hayatında önemli bir yere sahiptir. Çünkü uzun vadede birey gelecek için hedeflediği bir kariyere sahip olmak istemektedir. Bu kariyer hedefine birkaç yıl içerisinde $\mathrm{Z}$ kuşağ dahil olacaktır. Yakın zamanda bu kuşağın iş yaşamında yerini almaya başlayacağı ve $Y$ kuşağı ile ortaya çıkan farklı değer yargılarının devamı, Z kuşağı bireyleri tarafından sağlanacaktır (Metin ve di $\breve{g}, 2017$ ). Dolayısıyla (Taş ve diğ., 2017)'in yapmış olduğu geleceğimiz olan $Z$ kuşağının çalışma hayatına muhtemel etkileri çalışmasında da görüldüğü üzere bu kuşak bireylerinin teknoloji ile büyük gelişim gösterdiği ve işletme yapılarında da bu teknoloji ile iç içe olacakları çalışmanın içeriğinde önemle vurgulanmaktadır. Bu durumun hem örgüt içi performans üzerinde etkili olacağ 1 (Ceyhan, 2018) hem de teknoloji ile gelişim gösteren bu kuşak bireyleri işletme yapılarına çok büyük katkı saylayacakları düşünülmektedir. Şu halde bu kuşaktaki bireylerin kariyer hedefleri de bu teknoloji ile gelişip şekillenecektir. Bu sebeple şirket sahiplerinin bu kuşak bireylerinin kariyer hedefleri için uygun bir çalışma ortamı yaratmalarının önemini kavramaları gerekmektedir. $\mathrm{Bu}$ araştırmanın kimi varsayım ve sınırlılıkları bulunmaktadır. Araştırma kapsamında, Isparta ilinde bulunan liselerde bulunan öğrencilerin, bilgi toplama aracı olarak anket sorularına vermiş oldukları cevaplar gerçek durumu yansıttığı varsayılmaktadır. Isparta ilinde bulunan liselerde rastgele seçilmiş olarak yapıldığından, araştırma bulguları sorulara cevap veren öğrenciler ile sınırlıdır. Tüm bu sebeplerden dolayı yapmış olan çalışma genellenememektedir. Genelleme yapılabilmesi için daha geniş çaplı örneklemler üzerinde çalışma yapılması gerekmektedir. Bu durum ise diğer araştırmalar için öneri niteliğindedir. 


\section{KAYNAKÇA}

Adıgüzel, Orhan, Batur, Zeynep, H. ve Ekşili Nisa, (2014), "Kuşakların Değişen Yüzü ve Y Kuşağı ile Ortaya Çıkan Yeni Çalışma Tarzı: Mobil Yakalılar”, Süleyman Demirel Üniversitesi Sosyal Bilimler Enstitüsü Dergisi, (19): 165-182.

Akdemir, Ali ve Konakay, Gönül (2014), "Y Kuşağının Kariyer Algısı, Kariyer Değişimi ve Liderlik Tarzı Beklentilerinin Araştırılması", Muğla Sıtkı Koçman Üniversitesi İktisadi ve İdari Bilimler Fakültesi Ekonomi ve Yönetim Araştırmaları Dergisi, 2(2): 11-42.

Anafarta, Nilgün (2011), “Orta Düzey Yöneticilerin Kariyer Planlamasına Bireysel Perspektif”, Akdeniz Üniversitesi İktisadi ve İdari Bilimler Fakültesi Dergisi, 1(2): 1-17.

Aşkun, Neva, Cem (2006), "Örgütsel Stres ile Kariyer Planlaması Arasındaki İlişkiyi Belirlemeye Yönelik Bir Uygulama”, Dumlupınar Üniversitesi, Sosyal Bilimler Enstitüsü, İşletme Anabilim Dalı, Yayınlanmamış Yüksek Lisans Tezi, Kütahya.

Atay, Şeynur (2006), “Kariyer Yönetiminin Örgütsel Bağlllı̆ga Etkisi”, Afyon Kocatepe Üniversitesi, Sosyal Bilimler Enstitüsü, İşletme Anabilim Dalı, Yüksek Lisans Tezi, Afyon.

Aydemir, Durmuş, Ali (2018), "Gastronomi ve Mutfak Sanatları Eğitimi Alan Üniversite Öğrencilerinin Kariyer Beklentileri: Lisans Öğrencilerine Yönelik Bir Araştırma”, Nevşehir Hacı Bektaş Veli Üniversitesi, Sosyal Bilimler Enstitüsü, Turizm İşletmeciliği Anabilim Dalı, Yüksek Lisans Tezi, Nevşehir.

Baş, Türker (2005), “Anket Nasıl Hazırlanır, Uygulanır Değerlendirilir”, Ankara, Seçkin Yayıncılık.

Başol, Oğuz ve Aydın, Çetin, Gülşen, (2014), “X Ve Y Kuşağı: Çalışmanın Anlamında Bir Değişme Var mı?” Electronic Journal of Vocational Colleges, 4(4): 1-15.

Bilici, Hatice (2015), "Turizm Eğitimi Almış Sektör Çalışanlarının Kariyer Beklentileri (Fethiye Örneği)”, Muğla Sıtkı Kocaman Üniversitesi, Sosyal Bilimler Enstitüsü, Turizm İşletmeciliği Anabilim Dalı, Yüksek Lisans Tezi, Muğla.

Bovée, Courtland, L., Thill, John V., Mescon, Michael H. (2007), “Excellence in Business”, Pearson Prentice Hall.

Büyükuslu, Fulden (2017), “Z Kuşağının İş Yaşamından Beklentileri Konusunda Bir Araştırma”, Bahçeşehir Üniversitesi, Sosyal Bilimler Enstitüsü, İnsan Kaynakları Yönetimi, Yüksek Lisans Tezi, İstanbul.

Ceyhan, Sefa (2006), "Kişilik Özelliklerinin Örgütsel Vatandaşlık Davranışına Etkisi: Beş Yıldızlı Otel İşletmelerinde Bir Araştırma”, Alanya Alaaddin Keykubat Üniversitesi Sosyal Bilimler Enstitüsü,Yönetim Organizasyon Programı, Yüksek Lisans Tezi, Alanya.

Ergeneli, Azize, İlsav, Arzu, Camgöz, Sait, M., Güler, Kümbül, B., Karapınar, Bayhan, Ekmekçi, Özge, T., Özgödek, Ferendeci, M., Özgödek, Doğan, G., Odabaşı, Atalay, N. ve Borluk, Akşimin, N. (2014), İnsan Kaynakları Yönetimi. Nobel Akademik Yayıncılık.

Eryiğit, Süleyman (2000), “Kariyer Yönetimi”, Kamu-İş Dergisi 6(1): 1-25.

Fox, A. (2011). Mixing It Up-Multi-generational discord can impede workplace relationships and lower engagement. HR Magazine-Alexandria, 56(5): 22-27.

http://www.tdk.gov.tr/index.php?option=com_gts\&arama=gts\&guid=TDK.GTS.572fb18ae,\%20Eri\%C 5\%9Fim\%20Tarihi:\%10.05.2019.

Keleş, Hatice, N, (2013). Girişimcilik Eğiliminin Kuşak Farkına Göre İncelenmesi, Sosyal Ekonomik Araştırmalar Dergisi, 13(26), 23-43.

Kyles, Dana (2005), "Managing your multigenerational workforce."Strategic Finance”, 87(6): 52.

Levickaite, Rasa (2010), "Generations X, Y, Z: How Social Networks Form the Concept of the World without Borders (the Case of Lithuania)", LIMES: Cultural Regionalistics, 3.(2): 170-183.

McWhirter, E. H., \& McWhirter, B. T. (2008). Adolescent future expectations of work, education, family, and community development of a new measure. Youth \& Society, 40(2): 182-202.

Metin, s ve Kızıldağ, Duygu (2017), "Kuşakların Kariyer Beklentilerinin Farklılaşması: Otomotiv Sektöründe Bir Araştırma”, Mustafa Kemal Üniversitesi Sosyal Bilimler Enstitüsü Dergisi, 14(40): 340-363.

Özdemir, Serkan (2010), “Ön Lisans Muhasebe Öğrencilerinin Kariyer Planlamasını Etkileyen Unsurlar: Ege Bölgesinde Bir Araştırma”, World of Accounting Science, 12(2): 103-121.

Özgen, Hüseyin ve Yalçın, Azmi (2010), “İnsan Kaynakları Yönetimi: Stratejik Bir Yaklaşım”, Nobel Kitabevi.

People, Havas (2016), "Marketing to Generation Z”, 1-28, http://havaspeopleblog.tumblr.com/, (Erişim Tarihi: 01 Aralık 2018).

Reeves, T. C., \& Oh, E. (2008). Generational differences. Handbook of research on educational communications and technology, 3, 295-303.

Sarığlu, Başak, Elif ve Özgen, Ebru (2017), “Z Kuşağı: İş Dünyası Yakın Geleceğin İş Gücünü Ne Kadar Tanıyor?”, Researcher: Social Science Studies, 5(4): 242-253.

Schwarz, Thom (2008), "Brace Yourself Here Comes Generation Y”, Critical Care Nurse 28(5): 80-85.

Sladek, Sarah ve Grabinger, Alyx (2014), "Gen Z Introducing the first Generation of the 21st Century Available at https://goo.gl/Iu5o2t (Erişim Tarihi: 01 Aralık 2018).

Strauss, William and Neil, Howe (1991), Millennials rising: The next great generation, Vintage.

Şen, Hatice (2012), "Hemşirelikte Psikomotor Beceri Öğretiminde Rehber İlkeler: Kalp Masajı Örneği” Dokuz Eylül Üniversitesi Hemşirelik Yüksekokulu Elektronik Dergisi, 5(4): 180-184. 
Tanoli, Mubashar Farooq (2016), “Understanding Career Planning: A Literature Review”, Munich Personel Repec, 16(2): 162.

Taş,Yunus H., Demirdöğmez, Mehmet ve Küçükoğlu Mahmut (2017), “Geleceğimiz Olan Z Kuşağının Çalışma Hayatına Muhtemel Etkileri”, OPUS Uluslararası Toplum Araştırmaları Dergisi, 7(13): 1031-1048.

Taşlıyan, Mustafa, Arı, Ülkü, Nazmiye ve Duzman, Burak (2011), "İnsan Kaynakları Yönetiminde Kariyer Planlama ve Kariyer Yönetimi: İIBF Öğrencileri Üzerinde Bir Alan Araştırması”, Organizasyon ve Yönetim Bilimleri Dergisi, 3(2): 231-241.

Tosun, Ülkü ve Güntaş, Selime (2018), “Üniversite Öğrencilerinin Kariyer Beklentileri ve Empati Eğilimleri”, European Journal of Managerial Research Dergisi, 2(2): 23-28.

Tuncer, M. (2011). Ergen Gelecek Beklentileri Ölçeğinin Türkçeye Uyarlanması, Electronic Turkish Studies, 6(3).

Tuncer, Murat (2011), "Yükseköğretim Gençliğinin Gelecek Beklentileri Üzerine Bir Araştırma”, Electronic Turkish Studies, 6(2): 935-948.

Türk Dil Kurumu, Büyük Türkçe Sözlük. http://www.tdkterim.gov.tr/bts/,(Erişim tarihi: 01 Aralık 2018).

Üzüm, Burcu, ve Uçkun, Seher (2015), "Büro Yönetimi ve Yönetici Asistanlığı Öğrencilerinin Demografik Özellikleri ile Kariyer Geleceği Beklentilerinin Ölçülmesi: Kocaeli MYO Örneği”, Kocaeli Üniversitesi Sosyal Bilimler Dergisi, 1(16): 71-80.

Williams, Raymond (2015), "Politics and Letters: Interviews with New Left Review", Verso Trade.

Yiğit, Zühal (2010), "X ve Y Kuşaklarının Örgütsel Tutumlar Açısından İncelenmesi ve Bir Örnek Olay”, Bahçeşehir Üniversitesi, Sosyal Bilimler Enstitüsü, İnsan Kaynakları Yönetimi, Yüksek Lisans Tezi, İstanbul. 